\title{
THE ROLE OF DEPRESSION, ANXIETY, AND STRESS AGAINST HYPERTENSION IN THE ELDERLY
}

\author{
PERAN DEPRESI, KECEMASAN DAN STRES \\ TERHADAP HIPERTENSI PADA LANSIA \\ Noviana Dewi ${ }^{1}$ \\ Faqih Purnomosidi ${ }^{2}$
}

\begin{abstract}
Submited :
8 Mei 2019

Revision :

13 Agustus 2019

Accepted :

16 Agustus 2019
\end{abstract}

\begin{abstract}
The purpose of this research is to determine the correlation of depression, anxiety and stress to blood pressure in the elderly. Hypertension has been treated with drug therapy and control of food intake so far, but there are not many treatments related to psychological factors that can cause hypertension. Psychological factors have a role in influencing the emergence of physical illness. This research uses a quantitative correlation method design with data collection using DASS Test to measure the level of depression, anxiety, and stress with validity of $0.266-0.769$ and reliability of 0.939 while blood pressure measurements were measured using sphygmomanometer. The research results showed that there was a very strong correlation between depression, anxiety and stress on blood pressure in the elderly with a correlation of 0.875 which means that the higher the level of depression, anxiety, and stress in the elderly, the higher the tendency of hypertension.

Keywords: Anxiety; Depression; Hypertension; Stress.
\end{abstract}

\begin{abstract}
ABSTRAK
Tujuan dari penelitian ini adalah untuk mengetahui hubungan antara depresi, kecemasan dan stres terhadap tekanan darah pada lansia. Hipertensi sejauh ini telah diterapi dengan obat dan mengontrol asupan makanan, tetapi tidak ada banyak perawatan yang berkaitan dengan faktor psikologis yang dapat menyebabkan hipertensi. Faktor psikologis memiliki peran dalam mempengaruhi munculnya penyakit fisik. Penelitian ini menggunakan desain metode korelasi kuantitatif dengan pengumpulan data menggunakan DASS Test untuk mengukur tingkat depresi, kecemasan, dan stres dengan validitas 0,266-0,699 dan reliabilitas 0,939 sedangkan pengukuran tekanan darah diukur menggunakan sphygmomanometer. Hasil penelitian menunjukkan bahwa terdapat korelasi yang sangat kuat antara depresi, kecemasan dan stres pada tekanan darah pada lansia dengan korelasi 0,875 yang berarti bahwa semakin tinggi tingkat depresi, kecemasan, dan stres pada lansia, maka semakin tinggi kecenderungan untuk hipertensi.
\end{abstract}

Kata kunci : Depresi; Hipertensi; Kecemasan; Stres.

\section{INTRODUCTION}

Old age is prone to various kinds of diseases, considering that at this stage of development there is a deterioration in the ability of cells due to the aging process so that vital organs become weak, followed by symptoms of degenerative diseases. Degenerative diseases experienced by

\footnotetext{
${ }^{1}$ Noviana Dewi, STIKes Nasional, Email : viana072@gmail.com

${ }^{2}$ Faqih Purnomosidi, Universitas Sahid Surakarta, Email : faqihpsychoum26@gmail.com
} 
the elderly include hypertension and various variants of cardiovascular disease. According to Babatsikou and Zavitsanou (2010) hypertension is very common in the elderly, based on the results of epidemiological surveys in the United States and Europe data obtained that the prevalence of hypertension in the elderly ranges from $53 \%-72 \%$. Hypertension is one of chronic diseases that cannot be cured but its severity can be prevented by modifying risk factors for hypertension. Hypertension is often referred to as the "silent killer" because it often arises without symptoms but is suddenly severe and causes complications in other organs (Lewis et al, 2011). The mortality rate due to complications of hypertension is reported to reach 9.4 million deaths worldwide each year (WHO, 2013).

The Basic Health Research Results (2013) showed that the prevalence of hypertension in Indonesia was $26.5 \%$. Central Java Province is one of the provinces with the highest incidence of hypertension, which is around 26.4\% (Riskedas, 2013). The highest prevalence of hypertension occurred in the elderly, namely at the age of $45-54$ years old at $35.6 \%$, at the age of 55-64 years old at $45.9 \%$, at the age of $65-74$ years old at $57.6 \%$ and at the age of $>75$ years old $63,8 \%$ (Riskedas, 2013).

The number of hypertensive patients that increase every year is a risk factor for cardiovascular disease. Primary hypertension or known as essential or idiopathic hypertension is the most case of hypertension (Adrogue \& Madias, 2007). According to WHO hypertension and cardiovascular disease are the second most common diseases suffered by the elderly after arthritis (Nugroho, 2000).

Blood pressure is the power produced by the blood to each unit area of blood vessel walls (Guyton and Hall, 2008). Peak pressure occurs when the ventricle contracts, called systolic pressure, while diastolic pressure is the lowest pressure that occurs when the heart rests. Blood pressure is usually described by a comparison between systolic pressure and diastolic pressure, with normal values ranging from 100/60 to $140 / 90 \mathrm{mmHg}$ for adults. The average pressure of normal blood pressure is 120/80 $\mathrm{mmHg}$ (Smelzer and Bare, 2001). The factors that influence the condition of blood pressure include age, sex, stress, body mass index, smoking habits, physical activity, food and alcohol factors.

Negative emotions play a role in increasing the risk of cardiovascular disease and their derivatives include hypertension. Depression is one of the negative emotions that play a role in increasing mortality in patients with cardiovascular disease. Depression includes depression of mind, depression of feelings, physical depression (fatigue) and personality types with an easily depressed tendency (Doyle, et al, 2007).

Byrne \& Espnes (2008) suggests that stress takes a psychological role in three physical diseases, namely heart disease, hypertension and cardiovascular disease. The progress of the times and modernity requires more developed research because diseases including hypertension are caused by mechanisms of psychobiological factors.

Internal and external factors of anxiety can increase the risk of hypertension in the elderly. Internal factors include self-confidence, coping mechanism, level of maturity, personality type and feeling threatened. External factors include events of death, divorce, ethical dilemmas, changing jobs, changes in work status, social and cultural group pressures, and work stress (Pertiwi, 2017). According to Ringoir et al (2014) there was a prevalence of depression of 5\%, anxiety of 5\%, and type D personality of $8 \%$ in the elderly with hypertension.

The purpose of this research is to determine the correlation of psychological factors to blood pressure in the elderly. Psychological factors measured in this research include depression, anxiety and stress. Based on the results of the research then it can be mapped the description of the appropriate intervention by modifying psychological factors in patients with hypertension. 


\section{RESEARCH METHODS}

This research uses a correlational quantitative research design. The independent variables in this research include depression, anxiety, and stress. The dependent variable in this research is hypertension. Depression, anxiety and stress were measured using DASS Tests with validity $0.266-0.769$ and reliability 0.939 . Validity and reliability testing is carried out by using corrected items total corellation. The blood pressure variable was measured using sphygmomanometer with the category of hypertension namely blood pressure systole 140 Mmgg up and / or diastolic blood pressure $90 \mathrm{Mmhg}$ and up. This research uses a sampling technique with purposive nonrandom sampling with the criteria of being an active participant in the elderly posyandu and willing to be a participant in the research by first giving informed consent. Data normality test using Kolmogorov smirnov while linearity test uses Test of linearity. The research data were analyzed using multiple linear regression analysis with the help of SPSS. 23 program.

\section{RESULTS AND DISCUSSION}

In this research the percentage of the research sample based on age ie Middle Age $=$ between 45-59 years old as much as 30\%, elderly which is between 60-74 years old as much as $62 \%$, Older age which is between $75-90$ years old as much as $(8 \%)$, very old elderly which is more than 90 years old is none.

The percentage of the research sample by sex is $72 \%$ of women and $18 \%$ of men. This happened because there were more women as active participants in the posyandu because at that age more women were unproductive while men were still busy working so they were not active in the posyandu activities for the elderly.

Based on the results of the prerequisite test, to be able to do multiple linear regression analysis which includes the normality test and linearity test states that the data is normally distributed and linear. This is indicated by the results of the normality test using Kolmogorov smirnov where all variables both depression, anxiety, stress and blood pressure have a value of $>0.05$ (depression 0.107; anxiety 0.2 ; stress 0.2 ; blood pressure 0.09 ) so that it can be said that data is normally distributed.

Based on the results of linearity tests using the Test of linearity states that the linearity significance value is $0,000<0,05$ so that it can be categorized as linear data. Having fulfilled both normality and linearity requirements, the data is feasible to test hypotheses using multiple linear regression analysis techniques.

The following is a percentage of the research data included in the DASS test categorization as noted in table 1 .

Table 1.

Percentage of Research Results

\begin{tabular}{|l|lll|l|l|} 
Variable & normal & light & moderate & severe & very severe \\
\hline Depression & $0-9$ & $10-13$ & $\begin{array}{l}14-20 \\
(35 \%)\end{array}$ & $\begin{array}{l}21-27 \\
(52 \%)\end{array}$ & $\begin{array}{l}28+ \\
(13 \%)\end{array}$ \\
\hline Anxiety & $0-7$ & $8-9$ & $\begin{array}{l}10-14 \\
(5 \%)\end{array}$ & $\begin{array}{l}15-19 \\
(30 \%)\end{array}$ & $\begin{array}{l}20+ \\
(65 \%)\end{array}$ \\
\hline Stress & $\begin{array}{l}0-14 \\
(8 \%)\end{array}$ & $\begin{array}{l}15-18 \\
(12 \%)\end{array}$ & $\begin{array}{l}19-25 \\
(50 \%)\end{array}$ & $\begin{array}{l}26-33 \\
(30 \%)\end{array}$ & $34+$ \\
& & & & & \\
\hline
\end{tabular}

Table 1. shows that the level of depression of the research participants was in the moderate to very severe category. Moderate depression as much as $35 \%$, severe $52 \%$ and very severe $13 \%$. Anxiety is at a moderate to very severe level. Moderate anxiety $5 \%$, severe $30 \%$, and 
NOVIANA DEWI \& FAQIH PURNOMOSIDI, The Role Of Depression, Anxiety, And Stress Against Hypertension In The Elderly

very severe $65 \%$. Stress is in the normal to severe category. Normal stress level is $8 \%$, light $12 \%$, moderate $50 \%$ and severe $30 \%$.

The following is a percentage of data on research results included in the blood pressure classification as recorded in table 2 .

Table 2.

Percentage of Blood Pressure

\begin{tabular}{lcc}
\hline $\begin{array}{c}\text { Blood Pressure } \\
\text { Classification }\end{array}$ & $\begin{array}{c}\text { Systolic Blood Pressure } \\
\text { (Mmhg) }\end{array}$ & $\begin{array}{c}\text { Diastolic Blood } \\
\text { Pressure (Mmhg) }\end{array}$ \\
\hline Normal & $<120(3 \%)$ & $\leq 80$ \\
Pre-hypertension & $120-139(17 \%)$ & $80-89$ \\
Hypertension I & $140-159(35 \%)$ & $90-99$ \\
Hypertension II & $>160(45 \%)$ & $>100$ \\
\hline
\end{tabular}

Table 2 shows that as many as 3\% of participants had normal blood pressure, $17 \%$ were classified as pre-hypertensive, 35\% were classified as hypertension type I and $45 \%$ were classified as hypertension type II.

Based on the results of hypothesis test using multiple linear regression analysis techniques obtained an $\mathrm{R}$ value of 0.875 , it can be said that there is a very strong relationship between depression, anxiety, and stress on hypertension in the elderly.

The number of hypertensive patients who increase every year is a risk factor for cardiovascular disease. Primary hypertension or known as essential or idiopathic hypertension is the most case of hypertension (Adrogue \& Madias, 2007). According to WHO, hypertension and cardiovascular disease are the second most common diseases suffered by the elderly after arthritis (Nugroho, 2000).

Basic Health Research Results in 2013 showed that the prevalence of hypertension in Indonesia was $26.5 \%$. Central Java Province is one of the provinces with the highest incidence of hypertension, which is around 26.4\% (Riskedas, 2013). The highest prevalence of hypertension occurred in the elderly, namely at the age of $45-54$ years old at $35.6 \%$, at the age of 55-64 years old at $45.9 \%$, at the age of $65-74$ years at $57.6 \%$ and at the age of $>75$ years at $63,8 \%$ (Riskedas, 2013).

Age is related to high blood pressure (hypertension). The older a person is, the greater the risk of developing hypertension (Khomsan, 2003). At that age, the large arteries lose their flexibility and become stiff because of that the blood on each heart beat is forced to go through narrow blood vessels rather than usual and cause blood pressure to rise (Sigarlaki, 2006).

Another research conducted by Wahyuni and Eksanoto (2013) showed that women tended to suffer from hypertension than men. Women will experience an increased risk of high blood pressure after menopause, which is above 45 years old. It is because women who have not menopause are protected by the hormone estrogen which plays a role in increasing levels of High Density Lipoprotein (HDL).

Depression is one of the negative emotions that play a great role in increasing the risk of cardiovascular diseases including hypertension. The risk factors for cardiovascular disease increase especially if depression includes depression of the mind, depression of feelings, and depression in the condition of the body (somatic) supported by the type of personality D (Doyle, 2007).

According to Ringoir et al (2014) there was a prevalence of depression of 5\%, anxiety at $5 \%$ and type D personality at $8 \%$ in elderly people with hypertension. Anxiety is an emotion and an individual's subjective experience that is unclear and diffuse, which is related to feelings of uncertainty and helpless towards non-specific objects (Stuart, 2009). Anxiety is influenced by various things such as the level of self-confidence, coping mechanism, level of maturity, personality type and external threats. 
Physiologically, stressful situations activate the hypothalamus which then controls two neuroendocrine systems, the sympathetic system and the adrenal cortex system. The sympathetic nervous system responds to nerve impulses from the hypothalamus by activating various organs and smooth muscles that are under its control, among others, by increasing the heart rate and dilating the pupils. The sympathetic nervous system also signals the adrenal medulla to release epinephrine and norepinephrine to the bloodstream.

The adrenal cortex system is activated if the hypothalamus secretes CRF, a chemical that works on the pituitary gland located just below the hypothalamus. The pituitary gland then secrete the ACTH hormone which is carried through the bloodstream to the adrenal cortex which stimulates the release of a group of hormones, including cortisol, which regulates blood sugar levels. ACTH also signals other endocrine glands to release about 30 hormones. The effect of the combination of various stress hormones carried through the bloodstream plus the sympathetic branch neural activity of the autonomic nervous system plays a role in the response of flight or fight.

Physiological symptoms of the body against stress include: increased heart rate, blood pressure, and a tendency to experience cardiovascular disease, increased stress hormone secretions (eg adrenaline hormone), gastrotestinal disorders, physical fatigue, respiratory problems, skin disorders, headaches, lower back pain , muscle tension, sleep disorders, decreased immunity to the risk of cancer.

Adrenaline hormone increases heart rate, and increases blood pressure and increases energy supply. Stress can increase blood pressure, which in turn weakens and damages the lining of blood vessels, providing a place for settling lipids to form cholesterol plaques (Tambayong, 2000). Finally the lumen narrows, peripheral pressure increases and blood pressure rises, ventricles thicken (hypertrophy) and require more oxygen so that there is a meaningful correlation between coronary heart disease, hypertension, and stress (Tambayong, 2000).

\section{CONCLUSION}

There is a relationship between depression, anxiety, and stress on hypertension in the elderly. The relationship has a very strong correlation with a correlation of 0.875 . This can be interpreted that in this research where the age and sex factors are part of the control of the research sample. Depression, anxiety and stress factors have a contribution of $87.5 \%$ to the incidence of hypertension in the elderly. The remaining $12.5 \%$ is influenced by other factors that are not examined in this research which include food, drink, smoking, alcohol and sports factors.

This shows that physical illness is influenced by psychological factors, both thoughts and management of emotions, especially negative emotions. This has been proven based on the research results. Further interventions related to psychological treatment or therapy should be carried out in line with medical treatment. The approach in overcoming a disease should begin to be directed at handling psychobiological not just medical treatment but rather holistic handling.

\section{REFERENCES}

Androgue, H.J \& Madias, N.E. (2007). Sodium and Potasium in the Hypertension. NEJM, 356, 66-78.

Pathogenesis of

Babatsikou, F. \& Zavitsanou, A. (2010). Epidemiology of Hypertension in the Elderly. Health Science Journal, 4 (1). 
NOVIANA DEWI \& FAQIH PURNOMOSIDI, The Role Of Depression, Anxiety, And Stress Against Hypertension In The Elderly

Pertiwi, G.H. (2017). Hubungan Tekanan Darah dengan Tingkat Kecemasan Pada Lansia Santa Angela di Samarinda. Media Sains, 10(1), 21-27.

Khomsan, A. (2003). Pangan dan Gizi Untuk Kesehatan. Jakarta: PT. Rajagrafindo Persada.

Lewis, S., Bucher, L., Heitkemper, M. \& Dirksen, S. (2011). Medical Surgical Nursing: Assessment and Management of Clinical Problems. USA: Elsevier

Nugroho, W. (2000). Keperawatan Gerontologi. Jakarta: EGC

Ringoir, L., Pedersen, S. S., Widdershoven, J. W., \& Pop, V. J. (2014). Prevalence of psychological distress in elderly hypertension patients in primary care. Netherlands heart journal : monthly journal of the Netherlands Society of Cardiology and the Netherlands Heart Foundation, 22(2), 71-76. doi:10.1007/s12471-013-0502-z.

Balitbangkes. (2013). Riset Kesehatan Dasar 2013. Diakses dari http://www.depkes.go.id/article/view/MCN-20141230001/info-terkini-riskesdas2013.html.

Sigarlaki, H.J.O. (2006). Karakteristik dan Faktor Berhubungan dengan Hipertensi di Desa Bocor, Kecamatan Bulus Pesantren, Kabupaten Kebumen, Jawa Tengah, Tahun 2006. Makara, Kesehatan.10 (2), 78-88.

Stuart, G.W. (2009). Principles and Practice of Psychiatric Nursing (9 ${ }^{\text {th }}$ Edition). St.Louis: Mosby

Tambayong, J. (2000). Patofisiologi untuk Keperawatan. Jakarta: EGC

Wahyuni, dan Eksanoto, D. (2013). Hubungan Tingkat Pendidikan dan Jenis Kelamin dengan Kejadian Hipertensi di Kelurahan Jagalan di Wilayah Kerja Puskesmas Pucang Sawit Surakarta. Jurnal Ilmu Keperawatan Indonesia. 1 (1), 79-85.

World Health Organization. (2013). A Global Brief of Hypertension. Silent Killer: Global Public

Health Crisis.https://www.who.int/cardiovascular diseases/publications/global_brief_hyperte nsion/en/. 